\title{
Tall Cell Variant Thyroid Gland Papillary
} Carcinoma

National Cancer Institute

\section{Source}

National Cancer Institute. Tall Cell Variant Thyroid Gland Papillary Carcinoma. NCI

Thesaurus. Code C35558.

A morphologic variant of papillary carcinoma of the thyroid gland characterized by the presence of tall malignant follicular cells, arranged in papillary and trabecular patterns. Necrotic changes and high mitotic activity are present. 